\title{
Paradigm Changes in the Logic of Creative Approaches in Media and Political Practice
}

\author{
Prof. Dr. Hana Pravdová, PhD
}

\author{
University of Ss. Cyril and Methodius, Faculty of Mass Media Communication, Trnava, Slovak Republic
}

Email:hp.kaplna@gmail.com

\author{
Doi:10.5901/mjss.2015.v6n6s4p404
}

\begin{abstract}
The author of the study focuses on paradigm changes in the logic of creative approaches in media and political practice. The study applies a qualitative level of critical discursive analysis, the method of hermeneutic interpretation, as in the author's opinion it facilitates a selective and thorough approach to investigating the sources of theory. The study defines basic terms including paradigm change, creative approaches, media logic and post-democracy. The author considers them to represent processes, a specific quality and phenomena that have greatly influenced changes in the communications practices in these areas. The author operates on the premise that paradigm changes in the creative principles in media practices are conditioned by a relatively unilateral and schematic interpretation of events, the selection of topics and their classification in the backdrop of news and public relations and on the pages of periodicals according to an inverted hierarchy of importance vis-a-vis the individual events themselves. In addition, the author highlights the particular ways in which topics are processed based on the changing schematics and stereotypes in the work processes of the creators of media content. Based on the conclusions from the analysis and the interpretation of these findings in the broader context, the author sees a direct relationship between the consequences of the paradigm changes in creative approaches in media and practices of the world of politics, which reflect the crisis in media logic and factors conditioning the rise of post-democracy.
\end{abstract}

Keywords: paradigm shift, creative approaches, media logic, post-democracy.

\section{Introduction}

The media have been attributed a tremendous level of influence over all areas of human life by the professional circles and the general public. Research conducted by McCombs confirmed that media are able to table an agenda and deliberately and very efficiently influence the positions of recipients to the actual issue or problem tabled by the media. (2009) Particular emphasis is placed on the media's ability to influence political processes from a number of aspects, from taking and wielding power, to convincing and influencing voters, engaging in competition with political parties, etc. It is clear that the media represent a tremendous symbolic power and are also an important tool for forming public opinion and the conditions of modern democracies. This fact is widely known outside of researchers in the fields of media studies and other social science disciplines; it is recognised by figures active in politics, specifically politicians, as well. It is also apparent that the media and political parties are joined at the hip thanks to mutual conditionality, common interests and mutually beneficial relationships (Tökölyová, Modrzejewski, 2013, p. 38). These characteristics of the relationship between media and political powers are the source of an overriding question: To what extent does the logic used by media influence the nature of the operation of a democracy? If we understand the democratic system in society as a whole to be the result of the free will of the people as expressed in an election, then a legitimate question is to ask what mechanisms, factors and in what way does the thinking behind media content influence the final form of the political culture and the overall level of democracy.

This study explicitly focuses on paradigm changes in the logic of creative approaches in media and political practice in terms of seeking answers to just this question. A paradigm change in the logic of creative approaches is understood as the transformation of fundamental ideas, approaches and principles in the area of creative communication models and practices in specific areas of media and political practice. The study applies a qualitative level of critical discursive analysis, the method of hermeneutic interpretation, as it facilitates a selective and thorough approach to investigating the sources of theory reflecting this very issue. Relevant studies that have influenced research discourse in the area of media and sociological studies have the past three decades are also discussed. We also emphasize that reflection and analysis of the referenced paradigm shifts are examined from different platforms of opinions. In connection with the analysis of the issue, we define the terms paradigm shift, creative approaches, media logic, post-democracy, representative processes, specific quality and phenomena that significantly influence changes in the communication 
practices in these specific areas. These can be dated to the beginning of the 1990s to the present day. We reach a conclusion by which the paradigm changes in the logic of creative approaches in media practices are conditioned by a relatively unilateral and schematic interpretation of events, the selection of topics and their classification in a backdrop of news and public relations and on the pages of periodicals according to an inverted hierarchy of importance vis-a-vis the individual events themselves and by particular methods of processing different topics based on schematics and stereotypes in the work processes of the creators of media content. These methods of creating media communiques predefine specific categories of events and standardize the events themselves, their form and their interpretation. A reduction in the quality of the information is not uncommon in favour of attractiveness, storytelling, drama, etc. Conclusions drawn from analysis indicate a direct relationship between the consequences of the paradigm changes in creative approaches in media and political practice and the factors conditioning the rise of post-democracy. Within this developing discussion and the search for potential solutions to this issue, we refer to the potential, but more likely hypothetical solutions offered by the concepts of Kean and Thompson.

\section{Critical Analysis of Discourse and Discussion in Theoretical Concepts}

The primary advantage offered by hermeneutic analysis and the interpretation of the sources of theory is the relatively precise, yet rather subjective, definition of the primary characteristics of the paradigm changes in the logic of creative principles in media and political practice. We also base these efforts on the knowledge that the current level of research into social reality is very flexible and operative, as reflected by the solid level of theoretical reflection on this topic. This assertion is supported by the results of a host of important studies applying various analytical approaches, for instance constant comparison, hermeneutic interpretation of text units and different applications focused on quantitative content analysis. For reflection and analysis of the defined issue, it is typical that the question of the relationship between politics and media is examined from different platforms of opinion. On one side of the spectrum of opinion there is the work of the optimistic authors who claim that media continues to serve a democratic function, which is strengthened primarily by the activities of the so-called new media. The pessimistic authors are on the other side and highlight the specific practices of media creators (conditioned by different factors) that lead to the deformation of democratic rules and ultimately suppression of the ideal of the democratising function of the media. Three primary tracks of opinion among authors become evident with respect to the issue of the dominant influence of the media on forming opinions among voters. The first platform of opinion includes those authors who emphasize the strength and ability of political parties to influence the behaviour of the media (Chomsky, Herman, Gittlin, McChesney, Kean, Prokop and others). The second platform joins those authors who emphasize the strength and the ability of the media to influence political events (Mazzoleni, Patterson, Meyer, Thomson, Meyrowitz and others). The third opinion in formed by authors who focus on the consequences of the transformation of the relationship between media and politics in the spirit of a new media logic or a more sophisticated approach among political parties towards media communication (Altheide, Negrine, Manchini, Hallin, Holtz-Bacha and Papathanassopoulos, Ftorek and others).

The flexibility of social science reflection on relevant phenomena in different areas of social reality are also confirmed by timely exposure and analysis of growing trends in the creative principles applied in media practice over the last two decades of the previous century. Altheide was one of the first and most important authors to highlight this situation. In the middle of the 1990s Altheide published his work An Ecology of Communication: Cultural Formats of Control and gave the professional sphere the term of media logic. In connection with this specific area of research focus, he defined the term media logic as a phenomenon closely related to the issues of the ecology of communication (1995). Just as McLuhan had in 1965 (2011), Altheide derived his media concept from the assumption that there was a mutual interaction between the determinants of the communication process, information technologies, means of communication and thinking and social actions. This is based on the knowledge according to which two basic factors, technology and communication processes, in particular within television production, influence the final interpretation of socio-cultural reality. He considers media logic to represent processes via which the media present and transmit information (1995).

Researchers' efforts in investigating the issue of the relationship between media and the political sphere have been directed towards uncovering multi-layered problems such as the actual influence of the media on the creation of the political scene and the influence of political parties on the politics of media entities (public and commercial). Researchers have also focused on the extent to which the agendas of political entities are applied using specific tools, i.e. legislative, marketing, including lobbying, and other means based on pressure and ultimatums. Authors from different interdisciplinary positions and areas of research analyse the role of the media in gaining and wielding power and the causes, circumstances and the manner in which they exercise this power. One of the foremost interests of researchers is the level of democratisation in individual societal and political elements, its definitive characteristics and mission in 
comparison with the ideal democratic society based on the model of a liberal political system, the fundamental element of which is a popular election or consent of the people to the given government grouping. In this context, Ríchová states that the fundamental difference between a democratic system and other societal and political formations is the manner in which power is gained. "In non-democratic systems, the elites take power while, conversely, in democracies they offer up power". (2007) A number of problems related to the process of gaining power remain open, clearly indicating the unfair battle between a coalition of the holders of symbolic power (media enterprises) and the dominant interest groups (political parties and the expressions of an oligarchical-based form of capitalism).

Based on analysis of the situation in economically advanced societies at the turn of the Millennium, Petrusek claims that we are witnessing the establishment of a new phenomenon - post-democracy. In Petrusek's opinion, this is a real life phenomenon exhibiting a number of typical characteristics. The first is the fact that the votes cast by people in legitimate elections are not actually received through careful consideration; rather they are generated (primarily via mass media and political campaigns). The second characteristic refers to the connection between politics and economics. The political sphere is controlled by economic interests and indirectly by the interests of big business. The third characteristic is the fact that massive de-politicization has occurred as a result of growing social atomisation and degenerated individualism. The fourth characteristic is the crisis of representation manifested in the media depiction of social and political events in which the images presented by the media do not reflect reality. The fifth characteristic is represented by the idea that the government should always resolve fundamental problems. Problems, however, are passed on to private companies, thereby distancing the political system from the interests of the people. The sixth characteristic is the fact that the actual exercise of governmental power is less and less palpable and clear as it is losing its transparency. (2006) These characteristics make it clear that media enterprises intermediate communication between politicians and voters using different means, from providing information about political events to their evaluation or interviews with politicians. In this context, it is appropriate to revisit the ideas concerning modern Western-type societies elaborated by Habermas. According to Habermas, the public sphere has left the state's purview as a result of the dominance of the influence of strong economic groups in deciding on public matters. Habermas created a new and corporate model of power relationships in which a permanent brake has been applied on the influence of the public sector. The media have taken on a new role, and that is to manipulate public opinion. Politicians have come to be seen as passive consumers of a specific type of concept, only offering a construct of conventional and conforming ideas. (1989)

Different platforms of opinion and research combine the premise that the mission of the media is to provide basic information about political events or politicians seeking the favour of the voters. Media empower them in their own specific way with this task. They must rigorously balance their essential purpose and mission with the fact that their return on production costs and their financial success underpin all of their activities and efforts (with the exception of public media). Ultimately this is reflected in the quality of the information provided, which is subjugated by a creative credo that emphasizes aspects of escapism, catchiness, emotionality, storytelling, drama, etc. giving recipients the "feelings of relaxation, releasing the tension and stress associated with their day-to-day lives." (2013) The paradigm changes in the logic of creative approaches in media and political practice indicate a serious problem that is a sharp contrast to the traditional image of a deeply informed and cultivated media striving for increasing democratisation. This fact is emphasized by Gálik who confirmed through empirical evidence that television and the Internet to a large extend directly incorporate entertaining elements into all formats and genres. (2013) According to Postman, political communication has clearly come to increasingly resemble tabloids as a part of the transforming television culture over the past decade. Politics, which were long considered an exclusively conventional area, have come to represent a unique part of show business. (1999) Hudíková in this context emphasises that the appearances of political figures on television comprises a large part of the communication strategies of political parties, in particular in the periods leading up to elections, when the frequency of such appearances increases as the exchange of opinions gets sharper and the manner in which political presenters communicate changes. Politicians are aware that television reaches a large audience, thereby increasing the efficiency and intensifying their effect on potential and real voters. Strategies for winning voter sympathy and favour are underpinned by this very fact." (2014)

\section{Consequences of Paradigm Changes and Potential Solutions}

Given the spectre of just what this situation entails, the question of the relationship between the media and politics in the context of transparency and the legitimacy of gaining and wielding political power remains open. The framework for the effects of this media transformation on the logic of creative principles is clear given these facts, and in the process of media creation in particular. It underpins the methods of media production and distribution to recipients, binding journalists to the same approach in processing and interpreting topics and problems. Over the past two decades we have 
witnessed radical changes in the hierarchy of how content in news and news-publicity programs is managed and in the transformation and dynamism of composite processes and in the overall processing conducted by individual news and publicity units. The initial slots in a given program are assigned to topics that are more likely to entertain or shock the audience and are closer to tabloid fodder than serious content. The authors of these materials do not have the ambition of offering the audience the traditional journalistic bonus (explaining causes and consequences and identifying relationships and connections); rather they are more inclined towards creation and the interpretation of the essence of the given information based on a specific type of information entertainment. (2011) Many authors concur that the new media logic has been transposed into the manner in which specific topics are processed and their interpretation in the spirit of staging a media event. Hudíková emphasises in this regard that "different extremes appear in modern television production and may be identified in media content - in particular depictions of misfortunes caused by conflicts, intrigue, sex, vulgarity and ruthless competitiveness. Hudíková also refers to the manner in which these topics are processed: "tabloid headlines, rapid shots and sharp editing, slow motion movement and the cutting of shots, changes to colouring, intense lighting effects, loud and unbalanced sound, circus type effects for headlines and teasers, a constant background noise and high level of detail when shooting people". (2012)

Specific schematics of work procedures can be observed in the creation of news content applying a logic that predefines specific categories of events, a kind of standardization of their type, form and interpretation. Volko identifies the blurring line between the programs of public and commercial media, the lack of personalities and a preference for entertaining genres "given that colourful packaging for primitive content has come to dominate in media creation." (2010) According to Gáliková Tolnaiová, it is clear that the rising trend of infotainment in media content is continuing to strengthen thanks to the effects of new media, which offer very fast information with emphasis on elements of entertainment. (2013) It is true that professional creators of media content do utilise procedures when processing topics and encode messages through the selection and interpretation of events. They are able to professionally work with the lexicon, composition and emotional and rational elements based on the affect they want to induce in recipients. These are, however, determined by the paradigm of creative approaches, which define the overall arrangement of the genre. In giving preference to specific topics, the agendas of political parties or referring back to the same social or other phenomena, they have an advantage in that they have the direct attention of the recipients as they are afforded sufficient space to do so (e.g. the top story in a produced news or publicity program, extended minutes dedicated to the content, larger space on the front pages of newspapers, a higher frequency of news reports throughout the day in classic electronic media, the top news story on websites combined with the reactions of recipients, etc.). All of this visibility, publication, news, commentary, etc. simply reinforce its importance. As such, media creators define a preferential framework of topics, meaning they determine the specific events and their form and what answers and evaluations are more important and which are less important. Altheide in this context refers to common manipulation practice found in modern journalists when conducting publicity interviews, which Altheide considers an important expression of the transformation of media logic. Journalists, as opposed to previous practice, ask question that only bring to the fore the problem that they want to emphasize, regardless of the greater relevance of other questions. (1995)

Analysis of the functioning of media logic poses a fundamental question regarding the ethical platform of journalistic work and its impact on the overall fate of journalism as a whole. Despite increasing calls emphasizing the need for critical thinking skills, a review of media content and messages makes it clear that modern media enterprises with this transformed media logic of creation do not ensure the satisfaction or fulfilment of this need. Critical media theorists have raised the warning flag and stress the need to spread media awareness, or media literacy, among all age groups. As an example, Petranová stresses that "thinking critically means in-depth contemplation of the information a person obtains through various means." (2007) It is becoming clearer that there is a connection between the absence of critical thinking among a majority of the public and the change in the logic of creative approaches in media and political practice.

This is the reason why media analysts have begun to contemplate an ideal decision making process involving the media and a renaissance in the potential of direct democracy over the past two decades. In the spectrum of left-leaning media critics, an opinion has been formed according to which the public sector can only be restored through the strict decommodification of media enterprises and strengthening the standing of the public media services, which have rapidly lost their influence and standing since the 1980s. Kean (1991) formulates an idea in this context of a revised model of funds for public services. The basic prerequisite for fulfilling this idea is the creation and development of independent organisations financed using public funding and creating and establishing a cosmopolitan and plural civil society that is not under pressure from commercialism based on the principles of production and the exchange of goods. Public service media may only fully apply themselves in a post-capitalistic civil society operating on the basis of democratic state institutions. 
Thompson as a representative of the neo-liberal line of media critics criticises the model of funding for public services as too strong of a contrast between pluralism and production and the exchange of goods. The cultivation of pluralism in Thompson's opinion may require various forms of regulation in the media sector. This does not mean that media may only contribute to a truly pluralistic culture under the expectation that they are post-capitalistic. (2004) The contrast to the left-leaning concept is the idea of regulated pluralism, the fundamental aspect of which is the model of a "de-liberalised democracy". This interpretation of democracy is based on independent and active individuals able to form their own independent and reasoned judgements based on available information and consideration of different opinions. The institutional basis for this democratic model is configured to allow the application of a whole range of mechanisms facilitating the incorporation of a large quantity of individual judgements into collective decision making processes. "The de-liberalised understanding of democracy focuses attention on processes used to form judgements and make decisions. People are challenged to think about different alternatives and to consider the reasons and arguments for supporting specific proposals so they are able to create supported and sophisticated judgements based on a comparison of the individual opinions and positions." (2004)

While Thompson notes that current conditions may be reflective of such de-liberalised democracy, democracy itself to a large extent is a media democracy which in no way is a form of tele-democracy, which calls into question the realism of this type of democracy. In defence of the model Thompson notes that the ultimate fulfilment of the concept of a deliberalised democracy will depend on media institutions as a source of information and a means for expressing their opinions. In the case of such a relationship between democracy and media, this is the ideal form of direct democracy, which may ultimately lead to progress. Thompson sees such progress in the ability of recipients to form reasoned opinions, allowing them to be involved in decision making processes, which ultimately could lead to the restoration of democracy. (2004)

\section{Conclusions}

It is proven that paradigm changes in the creative principles in media practice are conditioned by a relatively unilateral and schematic interpretation of events, the selection of topics and their classification in the backdrop of news and public relations and on the pages of periodicals according to an inverted hierarchy of importance vis-a-vis the individual events themselves. The critical assessment of information by recipients has moved into the background, replaced by the primary interests of dynamic show offering various emotional triggers. The unwillingness and inability to perform in-depth analysis and form adequate opinions on the part of recipients has become a significant aspect of their metal capacities. The centre of attention for a great deal of media criticism has been the issue of the conditions, factors and various influences determining the ultimate form of media production. Particular attention is paid to resolving the relationships between media enterprises and the strategies of political parties, which have the primary objective of achieving a positive response from their publicity in the public. Indisputably they need the media, money and a real influence in order to coordinate the processes of forming positions, emotions and opinions among different target groups and potential voters. It is clear that paradigm changes in terms of creative approaches as manifested in a transformation of media logic play an important role in this process. The authors of political campaigns clearly understand this transformation, which has become evident in the last two decades of the 20th century and have flexible subordinated their media strategies and built relationships with media. This is clearly evident in the present day in the manner in which topics are processed and in the schematics and stereotypes of the work processes applied by media creators who pre-define specific categories of events, their typing, form and interpretation. Media logic is also influenced by the return on production costs and financial success, which underpins and undercuts all of their efforts. Ultimately, this is reflected in the quality of information and the aspects of catchiness, storytelling, drama, entertainment, in the style of a never-ending show, etc.

We are also witnessing the consequences of serious changes in the area in which democratic rules are applied when gaining and wielding power. A new quality of democracy, expressed by the term of post-democracy, has a number of symptomatic expressions: the will of the people is primarily formed through mass media and political campaigns; the political sphere is controlled by economic interests and indirectly by the interests of big business; massive depoliticisation is under way as a result of increasing social atomisation and degenerated individualism, and the fact that the images of politics, politicians and their promotions presented by the media do not correspond to reality, which reduces the transparency of political events. Critical consideration on the part of media analysts has led to a search for a solution to just such a situation. In this case their proposals have been shown to be marked by an ideological platform and the prism of a political position. Among left-leaning media critics, opinions have been formed according to which the democratic political scene can only be restored through the de-commodification of media enterprises and strengthening the standing of public service media, i.e. a return to a robust dual system operating on the principle of parity. Right-leaning analysts 
prefer the idea of regulated capitalism, the basis of which is the principle of a model of a de-liberalised democracy based on independent and active individuals. Such people should be able to develop their own independent and reasoned conclusions using available information and by evaluating different opinions. Despite evident attempts to compensate for the principles of the commercial aspects of the media scene, it is evident that neo-liberal critics are working with a relatively weak basis of argument in their concepts. They also overlook the factors determining the operation of current practices in media creation. Given these frameworks, the activities of media enterprises and media creators being unaffected is very difficult to imagine and non-simplified and superficial thinking among individuals regarding the fundamental issues of public affairs have been pushed to the extreme, even though this is based on the free choice of media. While the investigative range of opinion is polarised, these circumstances and premises highlight the direct relationships between the consequences of the paradigm changes of creative approaches in media and political practice, manifested in a relatively radical change in media logic, and the creation of a political agenda as well as the manner of its reception.

\section{References}

Althaide, D. (1995) An Ecology of Communication: Cultural Formats of Control. Hawthorre, p. 182

Gálik, S., Cenká, R. (2013) Twilight of Christianity in tele-view of the world. From homo religiosus to homo videns. European Journal of Science and Theology, October, Vol. 9, No. 5, pp. $225-236$

Gáliková Tolnaiová, S. (2013) Anthropological risks and the form that evil takes in the electronic media era, pp. 33 - 56. In Jozek, M. et al. Contemporary images of evil. Krakow, pp. 5 - 264

Habermas, J. (2000) Strukturální preměna veřejnosti (Structural Transformation of the Public). Prague

Hudíková, Z. (2014) Politici v televízii (Politicians on Television). Global Media Journal. Vol. 2, № 1, pp. 8-16

Hudíková, Z.: (2012) Extrémnost' - stigmatický prvok v televíznej produkcii (Extremism - A Stigmatic Element in Television Production). pp. $102-116$

In Matúš, J., Petranová, D. (eds.) Nové trendy v marketingu : spoločenská zodpovednost' (New Trends in Marketing: Social Responsibility). Trnava, pp. 2 - 479

Kean, J. (1991) The Media and Democracy. Cambridge,

McCombs, E. M. (2009) Nastolování agendy: masová média a veřejné mínění (Setting the agenda: Mass Media and Public Opinion). (2004) Camridge/Prague, pp. 173 - 176

McLuhan, M. (2011) Jak rozumět mediím. Extenze člověka. (Understanding Media. The Extensions of Man) Prague

Petranová, D. (2007) Podstata a význam kritického myslenia v mediálnej výchove (Fundamentals and Importance of Critical Thinking in Media Education). In Magál, S., Mistrík, M., Petranová, D. (eds.): Mediálne kompetencie v informačnej spoločnosti (Media Competencies in the Information Society). Trnava, p. 141

Petrusek, M. (2006) Společnosti pozdní doby (Society in the Modern Age). Prague, p.252-253

Postman, N. (1999) Ubavit se k smrti. Veřejná komunikace ve véku zábavy. (Amusing Ourselves to Death: Public Discourse in the Age of Show Business. (1985), New York) Prague, p. 140

Pravdová, H. (2011) Fenomén zábavy a úloha stereotypov v produkcii a recepcii mediálnej kultúry (The Phenomenon of Entertainment and the Role of Stereotypes in the Production and Reception of Media Culture). Communication Today, March, Vol. 2, No. 1, pp. 7-24

Radošinska, J., Višňovský, J. (2013) Aktuálne trendy v mediálnej kultúre (Current Trends in Media Culture). Trnava, p. 15

Říchová, B. (2007) Úvod do současné politologie (Introduction to Modern Political Science). Prague, p. 37

Thompson, B. J. (2004) Médiá a modernita. Sociálna teória médií. (The Media and Modernity. A Social Theory of the Media. (1995) Oxford) Prague, p. 193, p. 202, p. 205

Tökölyová, T., Modrzejewski, A. (2013). European Journal of Transformation Studies, 1 Role of mass media in foreign policy decisionmaking. (2), 37-47.

Volko, L. (2010) Kritika a kritická reflexia ako súčast' mediálnej kultúry (Criticism and Critical Reflection as a Part of Media Culture). Trnava, p. 113, In Magál, S, Petranová, D, Solík, M. (eds.) K problémom mediálnej komunikácie I (The Issue of Media Communication I). Trnava pp. $11-607$. 